\title{
Eel Cookies Supplement and Incidence of Diarrhea in Children Aged 12-24 Months
}

\author{
Nur Eva Aristina, ${ }^{1}$ Dedi Rachmadi, ${ }^{2}$ Dewi Marhaeni Diah Herawati, ${ }^{3}$ \\ Hadi Susiarno, ${ }^{4}$ Dida Akhmad Gurnida, ${ }^{2}$ Deni Kurniadi Sunjaya ${ }^{5}$ \\ ${ }^{1}$ Midwifery Department, Politeknik Kesehatan Kementerian Kesehatan Malang, Malang, Indonesia, \\ ${ }^{2}$ Department of Child Health, Faculty of Medicine, Universitas Padjadjaran/Dr. Hasan Sadikin General Hospital, \\ Bandung, Indonesia, ${ }^{3}$ Department of Biomedical Sciences, Faculty of Medicine, Universitas Padjadjaran, \\ Sumedang, Indonesia, ${ }^{4}$ Department of Obstetrics and Gynecology, Faculty of Medicine, Universitas \\ Padjadjaran/Dr. Hasan Sadikin General Hospital, Bandung, Indonesia, ${ }^{5}$ Department of \\ Public Health, Faculty of Medicine, Universitas Padjadjaran, Bandung, Indonesia
}

\begin{abstract}
Diarrhea is one of the main causes of death in infants and toddlers in Indonesia. The Indonesian eel is a source of animal protein that contains high nutrients, including vitamin A and zinc, so it can be used to boost immunity. The objective of this study was to analyze the effect of eel cookies on the incidence of diarrhea in children. This was a double-blind randomized control trial (RCT) posttest study on 44 children aged 12-24 months at Garuda Public Health Center, Bandung city, who were selected using the simple random sampling method. The study was conducted for 2 months from January to February 2017. Data were analyzed using the Wilcoxon test. Results showed that there was an effect of eel cookies in reducing diarrhea incidence in toddlers $(\mathrm{p}<0.001)$, with no diarrhea condition seen among the toddlers among 18 children who had a history of diarrhea in the past and among 20 other children with no history of past diarrhea. In conclusion, eel cookies can reduce the incidence of diarrhea in children aged 12-24 months. Hence, it can be used as a functional food to improve child immunity as one of the efforts to prevent infectious diseases, especially diarrhea.
\end{abstract}

Key words: Diarrhea, eel cookies, supplementation

\section{Suplementasi Cookies Ikan Sidat terhadap Kejadian Diare pada Balita Usia 12-24 Bulan}

\begin{abstract}
Abstrak
Penyakit diare merupakan salah satu penyebab kematian utama pada bayi dan balita di Indonesia. Ikan sidat merupakan salah satu sumber protein hewani yang banyak mengandung vitamin A dan seng sehingga dapat meningkatkan kekebalan tubuh. Tujuan penelitian ini adalah menganalisis pengaruh pemberian cookies ikan sidat terhadap kejadian diare pada balita. Desain penelitian dengan randomized controll trial (RCT) posttest group design dengan double blind. Subjek penelitian adalah balita usia 12-24 bulan di Puskesmas Garuda Kota Bandung sebanyak 44 responden. Penelitian dilakukan selama 2 bulan mulai Januari-Februari 2017. Pengambilan sampel dilakukan secara acak sederhana. Analisis data menggunakan Uji Wilcoxon. Hasil penelitian menunjukkan pengaruh pemberian cookies ikan sidat terhadap penurunan kejadian diare pada balita $(\mathrm{p}<0,001)$, yaitu tidak ada perubahan kondisi balita dari tidak diare menjadi diare dan terdapat 18 balita yang pernah memiliki riwayat penyakit diare mengalami perubahan setelah diberikan perlakuan sehingga tidak mengalami diare, sedangkan 20 orang di antara yang tidak memiliki riwayat penyakit diare setelah mendapatkan perlakuan tetap tidak mengalami diare. Simpulan, terdapat pengaruh pemberian cookies ikan sidat terhadap penurunan kejadian diare pada balita usia 12-24 bulan. Oleh karena itu, cookies ikan sidat dapat digunakan sebagai makanan fungsional untuk meningkatkan imunitas anak sebagai upaya pencegahan terhadap penyakit infeksi terutama diare.
\end{abstract}

Kata kunci: Cookies sidat, diare, suplementasi

Received: 30 July 2018; Revised: 10 May 2019; Accepted: 2 March 2020; Published: 30 April 2020

Correspondence: Nur Eva Aristina, S.S.T., M.Keb. Midwifery Department, Politeknik Kesehatan Kementerian Kesehatan Malang. Jln. Besar Ijen No. 77C, Malang 65112, East Java, Indonesia. E-mail: nearistina@gmail.com 


\section{Introduction}

Diseases, particularly diarrhea, is a primary cause of death in babies and toddlers in Indonesia, contributing $31.4 \%$ and $25.2 \%$ of the total number of deaths, respectively. Diarrhea is closely related to the nutrition issue, especially malnutrition. Diarrhea in all ages is one of the top four causes of death (13.2\%) with the rates of 214 per 1,000 people for all ages and 900 per 1,000 for toddlers in 2012. The highest incident of diarrhea for toddlers is seen in the 12 to 24-month-old age group (7.6\%). ${ }^{1,2}$

Low nutrition status is a significant risk factor that may cause diarrhea for babies and toddlers. ${ }^{3}$ The nutrition status related to malnutrition can increase the morbidity and mortality caused by the defense system of the human body, which continues to weaken and change body immunity. ${ }^{4}$

Nutrition status influences every single aspect of children's health, including growth, development, physical activities, and responses towards infectious diseases. The cause of malnutrition is lack of nutrients and lack of food absorption in the digestive system. ${ }^{5}$ Several studies have revealed that macronutrient or micronutrient deficiency might cause vulnerabilities to infectious diseases, including diarrhea. An infectious disease occurs due to reduced body's immunity, including cell immunity and IgA secretion.

Eel is an alternative source of protein which is better than beef because it has low cholesterol content and cheaper. Indonesia has a significant potential for the fishery, yet it is not corresponding with the increase in domestic fish consumption. ${ }^{6,7}$ The Indonesian eel (Anguilla spp.) is a fish that has an economic value both for local and foreign markets. The eel contains higher nutrients such as protein, fat, vitamin, and minerals such as phosphor, zinc, selenium, and iron when compared to other fish..$^{8-10}$

One of the by-products of eels is eel flour. ${ }^{11}$ This flour can be used as a material of food diversification as well as food supplements and functional food products. One of the forms of the functional food products made of eels is eel cookies. $^{11}$

This study aimed to analyze the effect of eelbased cookies consumption on the reduction of diarrhea incidence among toddlers aged 12-24 months old.

\section{Methods}

This was an experimental double-blind, randomized control trial (RCT) post-test group study. Neither the researchers nor the subjects of this study knew which intervention was provided to a particular subject. Subjects were chosen using a random sampling method and divided into two groups, namely the experimental group which received eel cookies and the control group which received cookies without eel content. The observed variable was the incidence of diarrhea. The eel cookies formulation was performed using chemical analysis to determine the water content, ash content, fat, protein, carbohydrate, vitamin $\mathrm{A}$, and zinc. The results of the analysis were used as the basis for the formulating cookies using the best formula and method, which should be suitable for cookies based on the nutritional value obtained from the list of food compositions. Experts then produced the cookies at the Baking Research and Development (BReAD) Unit of Bogor Agricultural University. The subjects in this study include toddlers ranging from 12 to 24 months old who lived in the area of the Garuda Public Health Center Bandung who met the inclusion criteria. This research was performed from January to February 2017.

The screening applied to the subjects through several stages. First, toddlers aged 12-24 months were registered and information on daily health care was obtained. These toddlers then received a physical check-up to determine their health status. Lastly, 40 research subjects were obtained and randomized to determine which toddlers went into the experimental group and which went to the control group.

Data collected consisted of cookies consumed during the intervention by the subjects. Data on cookies consumption were collected every week and recorded into the daily cookies consumption form. Food consumption was evaluated using the three-day estimated food recording method (2 days of consumption and one day without consumption) before consuming cookies and after 30 days of intervention. Data on food consumption were then converted into nutrient units and averaged to obtain daily consumption numbers. The Nutrisurvey 2007 application was used to convert basic data into nutrients data. The Wilcoxon test was chosen for statistical analysis.

The study protocol was approved by the 
Health Research Ethics Committee of the Faculty of Medicine, Universitas Padjadjaran, Bandung, Indonesia through the issuance of the ethical clearance letter number: 22/UN6.C1.3.2/KEPK/ $\mathrm{PN} / 2017$.

\section{Results}

The characteristics of the research subjects and the number of eel cookies consumed are presented in Table 1.

The difference in the average body weight and the protein, vitamin A, and zinc inputs before and after consuming the cookies are listed in Table 2.

The analysis of the effect of eel cookies on the reduction of diarrhea incidence is presented in Table 3 .

Table 3 presents that eel cookies affect diarrhea incidence reduction with $\mathrm{p}<0.001(\mathrm{p}=0.000)$, meaning that there was no change in the condition of toddlers from not having diarrhea to having diarrhea. There were 18 toddlers with a history of diarrhea who did not experience diarrhea after the treatment. Besides, 20 toddlers without any history of diarrhea maintain the absence of diarrhea after receiving the treatment.

\section{Discussion}

Table 1 presents the characteristics of subjects by the child sex, maternal occupational status, and maternal education level. Child sex distribution was similar between the intervention and control groups. The maternal occupational status did not differ greatly between the two groups with most mothers did not work $180 \%$ vs $70 \%$ in the intervention group and control group, respectively). The highest maternal education level was high school graduates $(45 \%$ in both groups). Most toddlers received exclusive breastfeeding $(65 \%$ vs $80 \%$ in the intervention and control groups, respectively). The incidence of diarrhea before the treatment did not differ greatly between the two groups, with $55 \%$ had a history of diarrhea in the intervention group and $45 \%$ of the toddlers in the control group had a history of diarrhea.

Education influences knowledge. The mother's knowledge about diarrhea will play an important role in improving the risk factors in her family that will eventually reduce the frequency of diarrhea occurrence among her family members. Lower knowledge and understanding

Table 1 General Characteristics of Subjects and Their Parents

\begin{tabular}{|c|c|c|}
\hline \multirow[b]{2}{*}{ Characteristics } & \multicolumn{2}{|c|}{ Group and Number of Subject } \\
\hline & $\begin{array}{c}\text { Eel Cookies } \\
(n=20)\end{array}$ & $\begin{array}{c}\text { Control Cookies } \\
(n=20)\end{array}$ \\
\hline \multicolumn{3}{|l|}{ Sex } \\
\hline Male & 9 & 9 \\
\hline Female & 11 & 11 \\
\hline \multicolumn{3}{|l|}{ Mother's occupational status } \\
\hline Working mother & 4 & 6 \\
\hline Non-working mother & 16 & 14 \\
\hline \multicolumn{3}{|l|}{ Mother's education status } \\
\hline Elementary school & 1 & 1 \\
\hline Junior high school & 6 & 3 \\
\hline Senior high school & 9 & 13 \\
\hline Higher education/equivalent & 4 & 3 \\
\hline \multicolumn{3}{|l|}{ Breastfeeding } \\
\hline Exclusive breastfeeding & 13 & 16 \\
\hline Non-exclusive breastfeeding & 7 & 4 \\
\hline \multicolumn{3}{|c|}{ Pre-intervention diarrhea occurrence } \\
\hline Occur & 11 & 9 \\
\hline Does not occur & 9 & 11 \\
\hline \multicolumn{3}{|c|}{ Post-intervention diarrhea occurrence } \\
\hline Occur & o & 2 \\
\hline Does not occur & 20 & 18 \\
\hline
\end{tabular}


Table 2 Analysis of Difference in Body Weight, Protein Input, Vitamin A Input, and Zinc Input

\begin{tabular}{lccc}
\hline Difference & \multicolumn{2}{c}{ Groups } & \\
\cline { 2 - 3 } & $\begin{array}{c}\text { Eel Cookies } \\
(\mathbf{n = 2 0})\end{array}$ & $\begin{array}{c}\text { Controlled Cookies } \\
(\mathbf{n = 2 0})\end{array}$ & p Value \\
\hline Body weight & & & \\
$\quad$ Before & 23.45 & 17.55 & 0.114 \\
$\quad$ After & 24.60 & 16.40 & 0.024 \\
Protein input & & & \\
$\quad$ Before & 21.78 & 19.23 & 0.489 \\
$\quad$ After & 23.68 & 17.33 & 0.086 \\
Vitamin A input & & & \\
$\quad$ Before & 17.28 & 23.83 & 0.072 \\
$\quad$ After & 23.83 & 17.18 & 0.072 \\
Zinc input & & & \\
$\quad$ Before & 21.50 & 19.25 & 0.579 \\
$\quad$ After & 23.25 & 17.75 & 0.126 \\
\hline
\end{tabular}

Note: *Mann-Whitney test

of diarrhea can result in a poorer ability to apply diarrhea information in daily life. Good maternal knowledge about diarrhea is expected to further improve the ability of mothers in handling and preventing diarrhea. ${ }^{12}$

The result of the analysis showed that there were no differences in the characteristics of the child's body weight before cookies provision ( $p$ value $=0.114$ ). After an intervention, a significant difference was seen between the bodyweight of toddlers in the intervention group and the control group ( $\mathrm{p}$ value $=0.024)$.

Bodyweight is the most important and most commonly used anthropometric measure in newborns (neonates). During infancy, weight can be used to observe the physical growth rate and nutritional status. Bodyweight is chosen because it has the best parameters and it is easy to use, easy to understand, and provides an overview of the current nutritional status. Bodyweight is one of the parameters for determining one's nutritional status. Several studies suggested that nutritional status has a significant risk factor in causing diarrhea in infants and toddlers. A low nutritional status in infants and toddlers is an important risk factor that can lead to diarrhea, especially in children aged o-24 months.

The result of the analysis of the characteristics of protein input in children before the intervention showed that no difference was seen between the intervention group and the control group $(p=0.489)$. After the intervention, this situation did not change $(\mathrm{p}=0.086)$.

The main function of protein for the body is to form new tissues and maintain the existing tissues. Protein can also function as a type of fuel if the body's energy needs are not met by carbohydrates and fats. Protein can regulate the balance of fluids in tissues and blood vessels by causing a colloidal osmotic pressure that can draw fluid from the tissues into the blood vessels. Another function of the protein relates to child

Table 3 Analysis of Effect of Eel Cookies to the Reduction of Diarrhea Incidence

\begin{tabular}{lccc}
\hline Diarrhea Occurrence Before and After & $\mathbf{n}=\mathbf{4 0}$ & $\begin{array}{l}\text { Mean Rank } \\
\text { (Min-Max) }\end{array}$ & p Value* \\
Negative rank & 0 & 0 & 0.000 \\
Positive rank & 18 & 9.50 & \\
Equal & 22 & & \\
\hline
\end{tabular}

Note: *Wilcoxon test 
growth and the development of child hormones, enzymes, and antibodies. The body's ability to fight infection depends on its ability to produce antibodies against organisms that can cause infections or to foreign substances that enter the body. The body also has the ability to detoxify toxins, which is controlled by enzymes, especially those found in the liver. In a state of protein deficiency, the body's ability to inhibit the toxic effects of toxic substances may decrease. ${ }^{13}$

There was no difference seen in the characteristics of vitamin A input between the intervention group and the control group $(p=0.072)$, which did not change after the intervention $(\mathrm{p}$ value $=0.072$ )

Vitamins are essential substances that are needed to help nutrient absorption and metabolism processes. A vitamin deficiency will cause health problems. Therefore, a certain amount of daily vitamin inputs need to be obtained, ideally from food. Other than its effect on eye health, vitamin A also acts as an antiinfection agent. The body's immune system function is reduced in vitamin A deficiency, making it susceptible to infectious diseases. If this occurs on the surface of the intestinal wall, diarrhea will occur. Children under five are susceptible to vitamin A deficiency. ${ }^{14}$

Analysis of zinc input before intervention showed no difference between the intervention group and the control group ( $\mathrm{p}$ value $=0.0579$ ). This stayed the same after the intervention (p value $=0.128$ ).

Zinc plays a role in immunity cells, namely in the function of the $\mathrm{T}$ cells and in the formation of antibodies by the B cells. Zinc also plays a role in several reactions that zinc deficiency will affect a lot of body tissues, especially during growth, and the body's immunity, especially against infectious diseases such as diarrhea. Zinc affects both the gastrointestinal system and, indirectly, the immune system. Zinc also plays a role in maintaining the integrity of the intestinal mucus through its function in cell regeneration and cell membrane stability. Zinc deficiency damages the epidermis and gastrointestinal mucus, facilitating an invasion of germs in the gastrointestinal tract. ${ }^{14}$

The average inputs of protein, vitamin $\mathrm{A}$, and zinc before and after the intervention were not significantly different between the intervention and the control groups. Toddlers aged $1-3$ years are passive consumers, so the input of food consumed is still very dependent on what is provided by the mother or parents. The pattern of food consumption in children under five is also still strongly influenced by the pattern of food consumption of parents or families.

The statistical analysis of the effect of providing eel cookies to the incidence of diarrhea showed that eel cookies consumption reduced the incidence of diarrhea $(\mathrm{p}=0.000)$. No diarrhea incident happened during the study and 18 toddlers with a history of diarrhea became better after consuming the cookies, which was apparent from the lack of diarrhea incidence. The 20 toddlers without a history of diarrhea still maintain the absence of diarrhea incidence after consuming the cookies.

Diarrhea prevention is important because diarrhea can cause death and deficiencies in infants and children. Efforts to reduce the incidence of diarrhea in children require the right intervention so infants and children become healthy and infectious diseases that may cause diarrhea can be prevented. The proven interventions to prevent the occurrence of diarrhea include improving child nutrition through the promotion of exclusive breastfeeding and complementary foods, provision of clean and safe drinking water, hygienic and healthy living behavior supported by the community and families, good sanitation and child immunization, and vitamin A and zinc supplements.

Findings in this study are in line with Asfianti et al. ${ }^{15}$ that suggested vitamin A and zinc supplement provision to children aged 12-60 months can reduce the incidence of diarrhea. The incidence of diarrhea has decreased from $28.40 \%$ to $26.1 \%$ after vitamin A and zinc supplements are provided. Adequate nutrients, especially vitamins and minerals, are important to maintain an optimum immune system. Because most vitamins and minerals cannot be synthesized by the body, the consumption of diverse and balanced foods is very important especially food that becomes the source of vitamins and minerals such as fruits, vegetables, and animal-based foods. ${ }^{16}$

A study by Widayani et al. ${ }^{17}$ on vitamin A and iron-containing biscuits to children under five showed significantly higher hemoglobin, ferritin, retinol, and total $\mathrm{G}$ immunoglobin levels at the end of the intervention. Another study that involved providing biscuits enriched with albumin protein of cork fish in children aged 4-5 years showed an increase in energy, protein, zinc, and Fe levels. ${ }^{18}$ 
Providing eel cookies with formulated nutrients that include protein, vitamin $\mathrm{A}$, and zinc is an effort to prevent infectious diseases, especially diarrhea. Eel cookies are a type of functional food that is enriched with eel head flour.

\section{Conclusion}

In summary, eel cookies provision affects the reduction of diarrhea incidence in children aged 12-24 months. Therefore, eel cookies can be used as a functional food to improve children's immune systems as an effort to prevent infectious diseases, especially diarrhea.

\section{Conflict of Interest}

The authors declare no conflict of interest.

\section{Acknowledgments}

We would like to thank Faculty of Medicine, Universitas Padjadjaran, Bandung, Indonesia as well as Malang Health Polytechnic, the Ministry of Health, PT. Carmelitha Lestari Bogor, and PT. Iroha Sidat Indonesia Banyuwangi.

\section{References}

1. Kementerian Kesehatan Republik Indonesia. Profil kesehatan Indonesia tahun 2013. Jakarta: Kementerian Kesehatan Republik Indonesia; 2014.

2. Indonesia Agency of Health Research and Development, Ministry of Health of Republic of Indonesia. Basic health research (Riskesdas) 2013 [Internet]. Jakarta: Indonesia Agency of Health Research and Development, Ministry of Health of Republic of Indonesia; 2013 [cited 2017 July 22]. Available from: http://labdata.litbang. kemkes.go.id/ccount/click.php?id=10.

3. Adisasmito W. Faktor risiko diare pada bayi dan balita di Indonesia: systematic review penelitian akademik bidang kesehatan masyarakat. MJHR. 2007;11(1):1-10.

4. Khalili B, Hart A, Mardani M, Khalili M, Mcardle F, Cuevas L. Diarrhea-associated micronutrient deficiencies and risk of subsequent diarrhea in admitted children to Hajar hospital in Shahrekord, Iran. Arch Clin Infect Dis. 2007;2(3):121-8.

5. Rodríguez L, Cervantes E, Ortiz R.
Malnutrition and gastrointestinal and respiratory infections in children: a public health problem. Int $\mathrm{J}$ Environ Res Public Health. 2011;8(4):1174-205.

6. Sokib N, Palupi NS, Suharjo B. Strategi peningkatan konsumsi ikan di Kota Depok, Jawa Barat. Manaj IKM. 2012;7(2):166-71.

7. Utami DP, Gumilar I, Sriati. Analisis bioekonomi penangkapan ikan layur (Trichirus sp.) di Perairan Parigi Kabupaten Ciamis. JPK. 2012;3(3):137-44.

8. Okfrianti Y, Kamsiah, Veli DG. Pengaruh penambahan tepung ikan sidat (Anguilla spp) pada pembuatan tortilla chips terhadap nilai gizi, kadar air dan daya terima organoleptik. JSPI. 2013;8(2):139-52.

9. Polak-Juszczak L, Robak S. Macro- and microelements in eel (Anguilla anguilla) from the northern regions of Poland. J Elementol. 2015;20(2):385-94.

10. Suseno SH. Fatty acid profiles of tropical eel (Anguilla sp.) by-products. Adv J Food Sci Technol. 2014;6(6):802-6.

11. Tarau E. Pengaruh kombinasi tepung ikan sidat (Anguilla marmorata (Q.) Gaimard.) dan tepung terigu terhadap kualitas biscuit crackers [undergraduate thesis]. Yogyakarta: Universitas Atma Jaya Yogyakarta; 2011 [cited 2018 February 20]. Available from: http://e-journal.uajy.ac.id/1547/.

12. Fathia H, Tejasari M, Trusda SAD. Hubungan tingkat pendidikan dan pengetahuan ibu tentang diare dengan frekuensi kejadian diare balita di wilayah kerja Puskesmas Tamansari Bandung Oktober 2013-Maret 2014. GMHC. 2015;3(1):13-8.

13. Yunita R, Anggraini M, Wiyono S. Hubungan antara asupan protein, zink, vitamin A dan kejadian infeksi saluran pernafasan akut (ISPA) non pneumonia pada balita di RW o6 Kelurahan Cempaka Putih Kecamatan Ciputat Timur Tangerang Selatan. Nutrire Diaita. 2014;6(2):99-113.

14. Arnisam, Salfiyadi T, Lura LS. Hubungan asupan mineral zinc (seng) dan vitamin A dengan kejadian diare pada balita di Kecamatan Seulimeum. INJ. 2013;4(3):6673.

15. Asfianti F, Nazir HM, Husin S, Theodorus. Pengaruh suplementasi seng dan vitamin A terhadap kejadian ISPA dan diare pada anak. Sari Pediatri. 2013;15(2):93-8.

16. Siswanto, Budisetyawati, Ernawati F. 
Peran beberapa zat gizi mikro dalam sistem imunitas. Gizi Indon. 2013;36(1):57-64.

17. Widayani S, Syarief H, Sulaeman A, Setiawan B, Muhilal. Efikasi dan preferensi biskuit yang difortifikasi vitamin A dan zat besi (Fe) dan kaitannya dengan konsumsi, status gizi, dan respons imun anak balita [dissertation]. Bogor: IPB; 2007 [cited 2018 April 30].
Available from: https://repository.ipb.ac.id/ handle/123456789/40899.

18. Sari DK, Marliyati SA, Kustiyah L, Khomsan A. Role of biscuits enriched with albumin protein from snakehead fish, zinc and iron on immune response of under five children. Pakistan J Nutr. 2014;13(1):28-32. 